\title{
SPECIALIZATION OF JUDGES FOR SETTLEMENT OF MARRIAGE DISPUTES
}

\begin{abstract}
The specialization of judges and/or specialized courts, as the reality of modern legal systems, take many forms: a specialized judge dealing with a limited legal area or cases relating to a particular factual situation in certain areas (such as, e.g. family law), specialized councils at existing courts (e.g. family council) or separate special courts (e.g. family courts). Modern family law defines a divorce judge as mediator, controller and protector of children's interests, as well as of the balance of interests of spouses, whose main role is the consensual and complete regulation of the consequences of the marriage dissolution and, in other cases, the resolution of the divorce dispute by judgement on merits based on all the evidence presented.

Such a complex court role requires not only an in-depth knowledge of legal matter but also a multidisciplinary approach to dispute resolution and imposes a specialization requirement in family matters, especially when it comes to high-conflict divorce cases. The subject of this paper is an analysis of the specialization of judges in the resolution of a high-conflict divorce dispute, taking into account all the advantages and disadvantages of specialization of judges, i.e. courts in that matter. Also, the aim of the paper is to consider the possibilities of better and more efficient work of the courts of the Republic of Serbia in this field, as well as the possibilities of specialization of judges in family law or the establishment of special family courts.
\end{abstract}

Key words: conflicts, divorce dispute, judge specialization, family courts.

* Judge of the High Court in Niš, e-mail: tanjasmitrovic79@gmail.com 


\section{INTRODUCTORY CONSIDERATIONS}

Family and marital conflicts that precede a judicial divorce contain emotional, psychological, sociological and cultural factors, which is why it takes more than knowing the law to resolve them. Upgrading the judicial knowledge of a judge with knowledge of sociology, psychology and other non-judicial disciplines is imposed not only by the nature of marital and family conflicts, but also by the country through the statutory duties and powers of the judiciary.

The modern concept of resolving a divorce starts from out-of-court mediation or judicial mediation, whereby the court procedure itself is based on the cooperation between the court and the spouses and involves the process of reducing the intensity of conflict, overcoming problems from the marital past and facilitating adjustment to new life roles, all with the aim of fully regulating the consequences of the divorce. In such a judicial process, the main role of the judge is to encourage communication between the spouses, to foster parental cooperation and to direct negotiations in order to settle the dispute amicably, i.e. to present all evidence and to resolve the dispute on its own merits in cases when no amicable settlement is possible. The feasibility of the court's role in resolving high-conflict divorce disputes depends largely on the specialization of judges, raising the question of the type and degree of specialization necessary to ensure the protection of fundamental rights and freedoms in the event of a conflicting divorce dispute and to provide quality judiciary while preserving the autonomy and independence of judicial authorities. The question that also comes up is where the line of a conflict is and what are the criteria for delimiting the jurisdiction and conduct of regular and specialized judges, that is, courts. Before pointing out all the advantages and disadvantages of the specialization of judges in this field, it is necessary to analyze the very concept of a high-conflict divorce, its consequences and the way of resolving it.

\section{HIGH-CONFLICT DIVORCE DISPUTE AND THE WAY TO RESOLVE IT}

In the case of a high-conflict divorce dispute, it is necessary to determine, first of all, the degree of conflict that has arisen, how the conflict reflects on the joint life of the spouses and children and what consequences it may have. In regulating family-legal relationships, cultural heritage and religious beliefs 
have a strong influence in certain countries, resulting in significant differences in family law norms. ${ }^{1}$

High-conflict divorce has at least three important dimensions to consider when assessing the incidence and its effects on marriage, i.e. spouses and children. Firstly, it is the domain of conflict, which may relate to disagreements about living together, financial support, property division, custody and access, values and ways of raising children.

Secondly, it is the tactical dimension of conflict, which can refer to the ways in which couples informally seek to resolve disagreements, including mutual avoidance, verbal aggression, physical and/or psychological aggression; or it can refer to the ways in which divorce cases are formally resolved through attorney negotiations, mediation or judgment. Thirdly, conflict has an attitude dimension, which refers to the degree of negative emotional feeling or hostility that can be expressed secretly or openly. ${ }^{2}$

Often, conflict in one area (such as financial matters) transitions to and activates conflict in another area (such as custody) and reduces the spouses' capacity for mutual cooperation regarding the best interests of the child/ children.

Modern family law advocates mediation as the most desirable way to resolve a divorce dispute. Mediation is defined as the use of a neutral third party in a trusted environment, to allow parents to clearly define issues, generate options, make priorities, and then negotiate differences and alternatives. In this dispute resolution method, the assumption is that the mediator can control the divorced couple's emotional conflicts and help them become rational, focused and goal oriented.

Generally, mediation in child custody disputes after divorce is widely advocated as an optional form because it allows parents to make their own decisions, avoid unnecessary government interference in family matters, and increase satisfaction and respect for the resulting agreement. ${ }^{3}$ Formal studies on the results of mediation and such court experience suggest that success rates in reaching agreements range from $40 \%$ to $70 \% .{ }^{4}$ The Family Law of the Republic of Serbia (2005), which changed the status of the child in accordance

\footnotetext{
${ }^{1}$ Šipovac R., Prelević S., (2010). Brak sa elementom inostranosti. Pravo-teorija i praksa 27 (910), p. 62.

${ }^{2}$ Ahrons, C. R., Rogers, R., H., (1987). Divorced families: A multidisciplinary developmental view, New York, W.W. Norton, p. 30.

${ }^{3}$ Ibid. pp. 415-428.

${ }^{4}$ Hauser, B. B., (1985). Custody in dispute: Legal and psychological profiles of contesting families. Journal of the American Academy of Child Psychiatry, (24), p. 575-82.
} 
with the provisions of the Convention on the Rights of the Child and provided for new rights of the child, also changed the concept of parental rights. The child lost the treatment of the real case and acquired the status of a legal entity to which a special spectrum of rights not arising from parental rights and duties belongs, and which the child enjoys in and outside the family. ${ }^{5}$

However, it is important to note that the "failure of mediation" is due to all the characteristics of a high-conflict divorce. Failure occurs when it comes to highly conflicted couples who are ambivalent about their marital status and who have severe psychopathologies or personality disorders ${ }^{6}$. It is often argued that mediation is not adequate for many dysfunctional families: in cases where there is domestic violence, where there are allegations of spousal and child abuse, or where it is claimed that one or both parents have severe psychological difficulties. ${ }^{7}$

In addition, it is difficult for parents to reach a consensus when they have very divergent perceptions of their children's needs and when there is a widespread distrust and lack of a rational decision-making process that mediation methods rely on. In a situation where the law itself excludes mediation, when there is no voluntary action or when mediation fails, a consensual arrangement of the consequences of the marriage dissolution is the task of the court, and when the spouses do not reach an agreement before the court, the court's task is to fully regulate the consequences of the dissolution of the marriage by judgment on merits, following the conducted evidence-based procedure.

The consequences of marital conflict and divorce are far-reaching, with the jurisdiction and duty of the courts differing in the legal systems of the countries, and may include deciding on: the independent or joint exercise of parental rights over minor children, maintaining the personal relationship of the child and the other parent, the contribution of the parents in support, the property relations between the spouses and the division of property jointly acquired during the marriage, the support of the ex-spouse, and often the decision on committed domestic violence or prevention thereof, whereby almost all modern legal systems share a common imperative of the best interests of children and the active role of a judge, whereby almost all modern legal systems share a common imperative - the best interests of children and the active role of the judge.

\footnotetext{
${ }_{5}^{5}$ Stanković G., (2014). Nova zakonska rešenja u postupku za produženje roditeljskog prava. Pravo -teorija i praksa 31 (10-12), p. 4

${ }^{6}$ Waldron, J. A., Roth, C. P., Farr, P. H., (1984). A therapeutic mediation model for child custody dispute resolution. Mediation Quarterly, (3), p. 5-20.

7 Tschann, J. M. et al., (1989). Family process and children's functioning during divorce. Journal of Marriage and the Family, (51), p. 431-444.
} 
A family court judge becomes a force within the family system, he or she is involved and morally and ethically compelled to manage cases in the children's interests. It would be difficult for a judge to remain neutral and not interfere with family life when making decisions that can ultimately change the way a family functions in everyday situations ${ }^{8}$. Family court judges often play an active role in finding, shaping and organizing the evidence collected, because judgments require complex information and have long-term consequences on the child's/children's life. ${ }^{9}$

Some authors note that most family court judges are adequately educated and experienced in family law, but have little formal education regarding child development, mental health and the family system. ${ }^{10}$ Furthermore, a court decision on divorce and regulation of the consequences of the dissolution of the marriage does not have to imply at the same time a resolution of a high-conflict divorce dispute, and therefore this court decision is often the basis for new litigation. These are the reasons that justify the specialization of judges and courts.

\section{POSSIBLE ADVANTAGES AND DISADVANTAGES OF JUDGE SPECIALIZATION}

Judge specialization has both positive and negative effects; both are difficult to evaluate in vitro because they are unpredictable and differ in different legal areas and systems. In general, the specialization of judges and courts arises from the need to adapt to legal changes, because in modern society the evolution of customs, social and economic changes, the development of medicine and technology are inevitably followed by legal changes, resulting in the continuous adoption of legal regulations. In such a situation, specialization ensures in-depth knowledge of legal matter, professionalization, greater expertise, experience and harmonization of case law. Further, specialization enables the acquisition of specific knowledge, i.e. upgrading of legal knowledge, with knowledge from various other disciplines, which results in a multidisciplinary approach to problem solving. Also, specialization contributes to the quality of judicial decisions, increases the efficiency of the judiciary

\footnotetext{
${ }^{8}$ Altbecker, A., (2003). Justice Through Specialisation? The Case of the Specialised Commercial Crime Court. ISS Monograph 76. Pretoria, p. 12.

${ }^{9}$ Henke, F., (2005). Specialised Court Systems. Comparative Paper Analysing the Possibilities of Implementing a Specialised Court System in India. (2018 August 20). Downloaded from: http:// www.fdrindia.org/old/publications/CourtSystemInIndia_PR.pdf.

${ }^{10}$ Rottman, D., (2000). Does Effective Therapeutic Jurisprudence Require Specialized Courts (and Do Specialized Courts Imply Specialist Judges)? Court Review Spring, p. 22-27.
} 
and legal certainty, while strengthening the authority of the judge and increasing the level of citizens' confidence in the judiciary. ${ }^{11}$

However, the situation regarding many legal systems shows that the judicial organization is largely unflinching with its arguments against the specialized judiciary; in these legal systems, the prevailing model is still the so-called general jurisdiction ${ }^{12}$. The Judge-General is an all-around judge who should be able to consider all the issues (factual and legal) raised in the cases before the court in which he or she is sitting. A possible lack of specialization is the risk of separation of specialized judges from the rest of the judiciary and the risk of sectorization of law and procedure, which may violate the principle of legal certainty and the right of access to a court in the case of the formation of a court in a restricted territorial area.

It can also give the impression that specialized judges are some kind of elite, which negatively affects public confidence in non-specialized judges, and that the excessive closeness of judges, prosecutors and lawyers during specialization can undermine the principle of judicial independence and impartiality. ${ }^{13}$ The link between the merits of the general justice and the preservation of impartial decision making is clear: moving from the premise that all judges are equally competent, it does not matter which judge decides the case, and therefore cases can be assigned at random, given that expertise in a particular field is not only necessary, but also considered as a negative trait that can potentially impair impartiality. ${ }^{14}$

Anyhow, behind the discussion about the advantages and disadvantages of judicial specialization lies a question that has no direct answer: in what legal fields is judicial specialization justified and desirable, for, in theory, each legal area - considering only issues that conventionally fall within the field of civil and commercial justice - requires a certain measure of expertise, and therefore the application of case specialization can multiply the number of

\footnotetext{
${ }^{11}$ Opinion No.15 of the Advisory Council of the European Judges on the specialization of judges adopted at the 13th plenary meeting in Paris in 2012 (2019, August 05). Downloaded from: https:// rm.coe.int

12 Posner R., (2006). The Role of the Judge in the Twenty-First Century. (2014 July 05).

Downloaded from: https://www.bu.edu/law/central/jd/organizations/journals/bulr/volume86n5/ documents/PosNErv.2.pdf

13 Opinion No.15 of the Advisory Council of the European Judges on the specialization of judges adopted at the 13th plenary meeting in Paris in 2012 (2019, August 05). Downloaded from: https:// rm.coe.int

${ }_{14}$ Pring, G., Pring, C., (2010). Specialized Environmental Courts and Tribunals: The Explosion of New Institutions to Adjudicate Environment, Climate Change, and Sustainable Development at the Confluence of Human Rights and the Environment. Institute for Training and Research 2d Global Conference on Environmental Governance and Democracy, Yale Law School.
} 
specialized courts: business courts, labor courts, family courts, immigration courts, environmental courts and many others, even to the extreme of the socalled problem-solving courts, which seem to be at the last frontier of judicial specialization, because their real purpose is not to settle disputes but "create new responses to chronic social, human and legal problems." 15 Taking into account all the possible advantages and disadvantages of judicial specialization, the very complexity of family relationships, as well as the nature and consequences of marital conflict and divorce, it seems that judicial specialization is not only justified and desirable when it comes to high-conflict divorce disputes but also necessary. Another important question is which types of judicial specialization are most appropriate?

\section{THE FAMILY COURT AND THE SPECIALIZED FAMILY JUDGES}

A family court is a special court designed to deal with legal issues arising from family relationships. A family court is usually a consolidation of several types of family courts dealing with specific family problems, such as child courts and orphan courts. Family courts specifically address family law issues. These are civil courts and can be used for various types of family complaints. ${ }^{16}$

Specialized family courts are defined as tribunals with a narrowly focused jurisdiction, but with a mission to fully resolve the dispute and avoid the subsequent activation of other judicial or extrajudicial bodies. Judges who sit in a specialized family court are regarded as specialists and experts in the fields of law that fall within the jurisdiction of the court.

The idea of family courts is quite old. In the 19th century, the Court for Divorce and Matrimonial Causes was established in England to free the church courts from the burden of such cases. In the United States, the first family courts were established in 1910 and were called domicile courts. Today, the United States, with its dual court system, is one of the richest sources of family court practice. Family courts are created by special statutes that define the types of cases they deal with, such as custody, child neglect, juvenile

\footnotetext{
${ }_{15}$ Mak, E., (2008). Balancing Territoriality and Functionality. Specialization as a Tool for Reforming Jurisdiction in the Netherlands, France and Germany. International Journal for Court Administration, Berlin

${ }^{16}$ Tyler T., Procedural Justice and the Courts. (2007. September 10). Downloaded from: http:// www.proceduralfairness.org/Theory-and-Research/ /media/Microsites/Files/procedural-fairness/ Tyler.ashx
} 
delinquency, paternity, family crime. Most family courts do not deal with divorce, separation or annulment cases, although the civil court occasionally refers such cases to family court to determine child custody or modify alimony payments.

Another rich source is the judicial systems of Western European countries, in particular the United Kingdom, which has a highly developed system of family courts and chambers. Japan is one of the countries whose justice system has a very well-incorporated family court and well-specialized divorce litigation judges. ${ }^{17}$

The three main benefits associated with creating specialized courts are:

(i) encouraging better decision making as experts decide complex cases;

(ii) reduction of pending cases in general courts by moving selected categories of factually and/or legally complex cases to specialized courts capable of dealing with them, and

(iii) reducing the number of court hours required to handle complex cases in a way that they are being judged by legal and substantive experts. ${ }^{18}$

This practice transferred to family courts means that by assigning jurisdiction for a specialized family field to a special court, the courts of general jurisdiction are freed, and family court judges, as judges of specialized jurisdiction, have the opportunity to develop more expertise than their counterparts in the general jurisdiction, and to more effectively, more expeditiously and more comprehensively resolve the dispute, which directly improves the efficiency of the court system. Furthermore, the advantage may be that the introduction of special family courts reduces the costs of parties and the judicial system, because the specialized judge is also an expert, and the procedure before such a court involves the participation of specialized lawyers and other specialized participants. Attorneys appearing before a Judge-General, especially in unusually complex cases involving cases or legal issues that the Judge-General may be less familiar with, usually detail all relevant and useful information in the briefs and minutes. They do this both to educate judges and to lay the ground for appeal if the judge's decision fails to understand the nature of the dispute and the elements of the law they apply to the decision. ${ }^{19}$

\footnotetext{
17 Zimmer, M., (2009). Overview of specialized courts. International Journal for Court Administration, p. 10.

18 Rottman, D., (2000). Does Effective Therapeutic Jurisprudence Require Specialized Courts (and Do Specialized Courts Imply Specialist Judges)?. Court Review Spring, p. 22-27

${ }^{19}$ O'Connell, M. E., DiFonzo, J. H. (2006). The family law education reform project final report. Family Court Review, 44(4), p. 534.
} 
With the number of cases covering a wide range of areas of the law, the likelihood that the Judge-General will develop adequate expertise in any particular area of law or complex issue is low. In such a situation, the JudgeGeneral takes a long time to master the subject matter, and often needs research assistance, and since they do not reflect indirect expertise, they make decisions at the risk of being lower in quality and more prone to complaining. Specialized family courts, whose judges have greater expertise and experience in jurisdictions, are likely to make higher quality decisions that may not or should not be subject to appeal. ${ }^{20}$

Given their expertise and knowledge of family matters, specialized judges are more zealous and achieve a greater degree of uniformity in decisionmaking, with greater uniformity resulting in more consistent case law and predictability and, over time, fewer disputes or high-conflict divorce matters.

\section{SPECIALIZATION OF FAMILY JUDGES IN THE REPUBLIC OF SERBIA UNDER POSITIVE LEGISLATION}

The starting point of the Republic of Serbia in the regulation of domestic family relations is the modern concept of human rights, respect for the nature of family relations and minimal external intervention of the government, all in accordance with ratified international documents, European and international standards.

In positive Serbian law, a decision on divorce is made by a court in the procedure prescribed by law, and by agreement of the parties or by lawsuit according to legally determined divorce grounds. In both cases, the court decision on divorce also contains the decision on exercising parental rights over minor children, maintaining the personal relationship between the child and the parents and the amount of the parents' contribution in child support, with the best interests of the child being imperative, and in the case of a consensual divorce, the court decision on divorce contains the decision on dividing the jointly acquired property. ${ }^{21}$

Marital disputes in the Republic of Serbia are in the first instance tried by a panel composed of one judge and two lay judges. Judges must have specific knowledge in the field of child rights, and lay judges are selected from among professionals with experience in working with children and young

\footnotetext{
${ }^{20}$ Babb, B. A. (2008). Reevaluating where we stand: A comprehensive survey of America's family justice systems. Family Court Review, 46(2), p. 230.

${ }^{21}$ Porodični zakon, Službeni glasnik RS, br. 18/2005, 72/2011 - dr. zakon i 6/2015.
} 
people. ${ }^{22}$ In the second instance (appeal proceedings) a specialized panel of three judges is sitting. Such a composition of the court achieves a degree of specialization as a guarantee of the quality of the trial and the protection of the best interests of the children, but it is not a guarantee of the efficiency of the judiciary, since without continuous professional training of judges and jurors and without specialized court panels, a positive specialization in many respects does not contribute to better and more efficient work of the judiciary in family law matters. ${ }^{23}$

When it comes to high-conflict divorce cases, a divorce judgment, even when passed by a specialized panel, in regards to the applicable domestic regulations, often does not mean resolving the marital conflict or fully regulating the consequences of the conflict and divorce, so the parties seek protection and the exercise of their rights in new court proceedings.

Namely, it is the duty of the first instance panel acting on the divorce lawsuit to examine whether or not the marriage can be saved, and in the event that the marriage cannot be saved, decide on the divorce and regulate the consequences of the marriage in such a way that it will also decide on the exercise of parental rights over the children, the model of maintaining the personal relationship between the children and the other parent and the amount of contributions in the support.

If the final judgment is not voluntarily enforced, the party is compelled to initiate enforcement proceedings with the competent authority or to seek criminal protection by filing a criminal complaint with the competent prosecutor's office, and cases of filing new lawsuits to modify the decision on the exercise of parental rights, models of maintaining personal relations and the amount of child support contributions are not rare either. All of these procedures include the involvement of new participants, such as competent enforcement authorities, judges, and prosecutors who must also have specific knowledge in the field of child rights. In such a situation, the parties are forced to reiterate conflict facts from the marriage and parental life before the new participants in the proceedings, and there is a risk of secondary victimization while increasing the costs of the proceedings is inevitable. What also needs to be considered when discussing the specialization of family judges is the Rulebook on the Program and Methods for the Acquisition of Special Knowledge in the Field of the Rights of the Child by Judges in Family Relations Proceedings,

\footnotetext{
22 Šijački, V., (2006). Razvod braka, Novi Sad, Pokrajinski zavod za ravnopravnost polova, p. 5.

${ }^{23}$ In practice, judges receive a certificate of special knowledge in one-day training, and family judges, especially in smaller courts, do not deal solely with family relations disputes but act in different legal matters.
} 
adopted pursuant to Article 203 paragraph 4 of the Family Law ("RS Official Gazette", No. 18/05).

The Rulebook regulates the program and the manner in which judges who sit in family proceedings can acquire special knowledge in the field of child rights. The Rulebook program provides for the acquisition of additional theoretical and practical knowledge in the field of the rights of the child and the acquisition of effective trial skills. In addition to this knowledge, it is necessary to acquire social and psychological knowledge that will allow judges to better understand the diversity of family relationships, and most importantly, to successfully judge in the best interests of the child.

The special knowledge acquisition program covers specific thematic units, which aim to familiarize judges with the rights of the child, his or her position in divorce cases and the effective and timely protection thereof.

The program covers five thematic sections pertaining to the rights of the child, the legal consequences of marriage and common-law marriage dissolution, the opinion of the child and domestic violence. ${ }^{24}$

\section{CONCLUSION}

Bearing in mind the actual, local and functional jurisdiction of domestic courts and the peculiarities of court proceedings, as well as the domestic substantive family law, it is concluded that positive legal solutions do not guarantee the possibility of complete regulation of the consequences of a highconflict divorce dispute before the assigned family council and that greater efficiency can be achieved by forming special family courts.

Viewed from the aspect of better and more efficient work of the judiciary and legal certainty, the complexity of divorce issues, the comparative experience of other countries and the current tendencies of family law protection, as well as the fact that the Republic of Serbia is in the process of joining the European Union, make the priority reform in this field justified.

\footnotetext{
${ }^{24}$ Rulebook on the program and manner of acquiring special knowledge in the field of the rights of the child by judges adjudicating in family relations proceedings, RS Official Gazette, No. 44 dated May 26, 2006 (2019, November 09). Downloaded from: http://www.pravno-informacioni-sistem.rs/ SlGlasnikPortal/eli/rep/sgrs/ministarstva/pravilnik/2006/44/1/reg.
} 


\title{
Mitrović S. Tanja
}

Sudija Višeg suda u Nišu

\section{SPECIJALIZACIJA SUDIJA ZA REŠAVANJE BRAČNIH SPOROVA}

\author{
Re zime
}

Specijalizacija sudija i/ili specijalizovani sudovi, kao realna manifestacija modernih pravnih sistema, imaju različite oblike i mogu se pojaviti u vidu: specijalizovanog sudije koji se bavi ograničenom pravnom oblašću ili slučajevima koji se odnose na određenu činjeničnu situaciju u određenim oblastima (kao što je, na primer, porodično pravo), specijalizovanog veća na postojećim sudskim postupcima (npr. porodično veće) ili posebnim specijalnim postupcima (npr. porodični sudovi). Savremeno porodično pravo definiše sudiju za razvode kao posrednika, kontrolora i zaštitnika dečjih interesa, kao i ravnoteže interesa supružnika, čija je glavna uloga sporazumno i potpuno uređivanje posledica raskida braka $i$, u drugim slučajevima, rešavanje spora razvoda braka presudom na osnovu svih izvedenih dokaza.

Ovako složena sudska uloga zahteva ne samo veoma duboko poznavanje pravne materije, već i multidisciplinarni pristup u rešavanju sporova i nameće potrebu za specijalizacijom u porodičnim stvarima, posebno kada je reč o slučajevima razvoda braka sa izraženim sukobom supružnika.

Predmet ovog rada je analiza specijalizacije sudija u rešavanju slučajeva razvoda braka sa izraženim sukobom supružnika, uzimajući u obzir sve prednosti i mane specijalizacije sudija, tj. sudova po tom pitanju. Takođe, cilj rada je sagledavanje mogućnosti boljeg i efikasnijeg rada sudova Republike Srbije u ovoj oblasti, kao i mogućnosti specijalizacije sudija iz porodičnog prava ili osnivanje posebnih porodičnih sudova

Ključne reči: sukobi, spor povodom razvoda braka, specijalizacija sudija, porodični sudovi. 


\section{Literature}

1. Ahrons, C.R., Rogers, R.H., (1987). Divorced families: A multidisciplinary developmental view, New York, W.W. Norton.

2. Altbecker, A., (2003). Justice Through Specialisation? The Case of the Specialised Commercial Crime Court. ISS Monograph 76. Pretoria.

3. Babb, B. A. (2008). Reevaluating where we stand: A comprehensive survey of America's family justice systems. Family Court Review, 46(2), pp. 230-257.

4. Hauser, B.B., (1985). Custody in dispute: Legal and psychological profiles of contesting families. Journal of the American Academy of Child Psychiatry No.24, pp. 575-82.

5. Henke, F., (2005). Specialised Court Systems. Comparative Paper Analysing the Possibilities of Implementing a Specialised Court System in India. (2018 August 20). Downloaded from: http://www.fdrindia.org/ old/publications/CourtSystemInIndia_PR.pdf.

6. Krivični zakonik, Službeni glasnik RS, br. 85/2005, 88/2005 - ispr., 107/2005 - ispr., 72/2009, 111/2009, 121/2012, 104/2013, 108/2014, 94/2016 i 35/2019.

7. Mak, E., (2008). Balancing Territoriality and Functionality. Specialization as a Tool for Reforming Jurisdiction in the Netherlands, France and Germany. International Journal for Court Administration, Berlin.

8. O'Connell, M. E., \& DiFonzo, J. H. (2006). The family law education reform project final report. Family Court Review, 44(4), pp. 524-570.

9. Opinion No.15 of the Advisory Council of the European Judges on the specialization of judges adopted at the 13th plenary meeting in Paris in 2012 (2019, August 05). Downloaded from: https://rm.coe.int.

10. Posner R., (2006). The Role of the Judge in the Twenty-First Century. (2014 July 05). Downloaded from: https://www.bu.edu/law/central/jd/ organizations/journals/bulr/volume86n5/documents/PosNErv.2.pdf.

11. Pring, G., Pring, C., (2010). Specialized Environmental Courts and Tribunals: The Explosion of New Institutions to Adjudicate Environment, Climate Change, and Sustainable Development at the Confluence of Human Rights and the Environment. Institute for Training and Research 2d Global Conference on Environmental Governance and Democracy, Yale Law School.

12. Porodični zakon, Službeni glasnik RS, br. 18/2005, 72/2011 - dr. zakon i 6/2015. 
13. Rottman, D., (2000). Does Effective Therapeutic Jurisprudence Require Specialized Courts (and Do Specialized Courts Imply Specialist Judges)?. Court Review Spring, p. 22-27.

14. Rulebook on the program and manner of acquiring special knowledge in the field of the rights of the child by judges adjudicating in family relations proceedings, RS Official Gazette, No. 44 dated May 26, 2006 (2019, November 09). Downloaded from: http://www.pravnoinformacioni-sistem.rs/SlGlasnikPortal/eli/rep/sgrs/ministarstva/ pravilnik/2006/44/1/reg.

15. Stanković G., (2014). Nova zakonska rešenja u postupku za produženje roditeljskog prava. Pravo - teorija i praksa 31 (10-12), pp. 1-16.

16. Šijački, V., (2006). Razvod braka, Novi Sad, Pokrajinski zavod za ravnopravnost polova.

17. Šipovac R., Prelević S., (2010). Brak sa elementom inostranosti. Pravo teorija i praksa 27 (9-10), pp. 62-72.

18. Tschann, J.M. et al., (1989). Family process and children's functioning during divorce. Journal of Marriage and the Family (51), pp. 431-444.

19. Tyler T., Procedural Justice and the Courts. (2007 September 10). Downloaded from: http://www.proceduralfairness.org/Theory-and Research/ /media/Microsites/Files/procedural-fairness/Tyler.ashx.

20. Waldron, J.A., Roth, C.P., Farr, P.H., (1984). A therapeutic mediation model for child custody dispute resolution. Mediation Quarterly, (3), p. 5-20.

21. Zakon o izvršenju i obezbeđenju, Službeni glasnik RS, br. 106/2015, 106/2016 - autentično tumačenje, 113/2017 - autentično tumačenje i $54 / 2019$.

22. Zimmer, M., (2009). Overview of specialized courts. International Journal for Court Administration, p. 10. 